\title{
Original Article \\ Co-Benefits of Climate Change Mitigation for Public Transport in Different Cities of Vietnam
}

\author{
Nghiem Trung Dung ${ }^{1, *}$, Nguyen Thi Yen Lien², Tran Thu Trang ${ }^{3}$, Dao Duy Nam ${ }^{1}$ \\ ${ }^{1}$ School of Environmental Science and Technology, Hanoi University of Science and Technology, \\ 1 Dai Co Viet, Hanoi, Vietnam \\ ${ }^{2}$ Faculty of Transport Safety and Environment, University of Transport and Communications, \\ 3 Cau Giay, Hanoi, Vietnam \\ ${ }^{3}$ Faculty of Environment and Biotechnology, Van Lang University, \\ 45 Nguyen Khac Nhu, Ho Chi Minh, Vietnam
}

Received 26 July 2019

Revised 15 October 2019; Accepted 28 October 2019

\begin{abstract}
Potentiality of co-benefits for public transport at cities of different grades in Vietnam namely Ho Chi Minh city (special city), Da Nang (centrally-run grade I city) and Vinh (grade I city under the province) in 2013 was studied. Taxis in Da Nang and Vinh, and buses in Ho Chi Minh City were selected for the study. A same methodology was used for all cities. In each city, three areas and nine routes in inner city were selected for conducting this study. Information on the technical conditions of vehicles was collected by questionnaires. Traffic volume was determined by vehicle counting. The real-world driving data of vehicles were recorded by GPS technology. All collected data were processed to generate input files to run IVE model associated with base state and three proposed scenarios of climate change mitigation. Emission factors (EF) of air pollutants for these transport means were determined. Co-benefits of climate, air quality and health for the scenarios in three cities were assessed. The obtained results in this study can be used as a scientific basis for integrated air quality management in the cities in general and for air pollution control of public transport in particular.
\end{abstract}

Keywords: Co-benefits, public transport, emission factor, IVE model, Vietnam.

\footnotetext{
* Corresponding author.

E-mail address: dung.nghiemtrung@ hust.edu.vn

https://doi.org/10.25073/2588-1094/vnuees.4419
} 


\section{Introduction}

Road transport was reported being the most important source of air pollution in urban areas $[1,2]$. The major air pollutants come from gasoline and diesel engines including carbon monoxide, nitrogen oxides, non-combustible hydrocarbons, and particulate matter that also were indicated as greenhouse gases causing climate change (GHGs). Although the emission control technologies for motorcycles cars are enhanced gradually, the number of vehicles keeps raising significantly. Beside motorcycles, other on-road vehicle means, such as bus and taxi, have also increased in recent years in many big cities [1]. The number of taxi in Da Nang in 2007 was 424 but in 2012, the data were double higher than the number in 2007 while quantity of Mai Linh taxi was 100 and 500 in 2007 and 2012, respectively (DOT of Da Nang, 2013; Mai Linh Group, 2009). On the other hand, the number of bus in Ho Chi Minh City increased during 2004 - 2008 but decreased from 2008 to 2012 because a lot of old buses was removed (CCPT, 2012). Because of increasing vehicle quantity, air quality becomes worse and worse. Air pollution is considered being the biggest environmental threat to human health in Vietnam, even more serious than traffic accidents. Heart diseases and stroke are the most common causes of premature mortality associated with air pollution, accounting for $80 \%$ of early deaths; followed by lung diseases and lung cancer [3]. However, there is no detailed analysis of emission of public transport fleets as well as the health benefits of climate change mitigation according to various emission control strategies. Hence, to assess the effectiveness of these measures, this study is highly required.

\section{Methodology}

\subsection{Research design}

The methodology of this study is presented in Figure 1.
The primary data collection of taxis was conducted in Vinh and Da Nang while buses were studied in Ho Chi Minh City (HCMC) following the IVE method which consist of questionnaire survey, GPS recording and vehicle flow monitoring [4]. The secondary data included the vehicle population, fuel characteristics, engine technology, meteorology, and on-road driving patterns (running distance and number of starts). All primary and secondary data were used to generate the input files for conducting relevant EFs for each study area. Three road types (highways, arterial and residential roads), that were selected to run through three zones representing each city including higher income (zone A), commercial (zone B) and lower income (zone C). The selected roads for each study area are shown in Table 1.

\subsection{Data collection and processing}

\section{Parking lot questionnaire survey}

The questionnaire survey was carried out to identify the technology type shares of buses in HCMC, taxis in Da Nang and Vinh. The sample size was determined to provide a $90 \%$ confidence estimate following the method illustrated in Taro Yamane. The numbers of vehicles subjected for survey were 2953 buses in HCMC, 923 taxis in Da Nang and 761 taxis in Vinh. The information of model year, weight, fuel, engine, exhaust control, age, daily traveled distance and traveled total distance were collected to better determine the vehicle technologies.

\section{Vehicle Kilometers Traveled (VKT) estimation}

The regression analysis of the accumulated odometer readings of 100 surveyed buses in HCMC, 120 surveyed taxis in Da Nang and 100 surveyed taxis in Vinh $\left(\mathrm{O}_{\mathrm{v}}\right)$ in $\mathrm{km}$ and the vehicle age in years was conducted. The $\mathrm{O}_{\mathrm{v}}$ value that is presented in Equation (1) was calculated using the average age of vehicle fleet obtained from the survey to estimate the average annual usage of a vehicle (Tv), km/year.

$$
T_{v}=O_{v, a+0.5}-O_{v, a-0.5}
$$




\section{Driving activities and Vehicle Specific Power} (VSP) distribution

The vehicle driving data were recorded every second using Garmin GPSmap76CSx and Garmin eTrex Vista HCx attached on the vehicle while it was running on different roads in HCMC, Da Nang and Vinh. The recorded data included information of longitude, latitude, altitude, and speed. GPS monitoring for bus was conducted in the period of 16 hours that is daily operation time of bus, while for taxi, GPS data was produced $24 / 24$ hours. The recorded data were used to determine the driving pattern in the form of VSP developed by Jimenez's method (1999) [5]. There are 20 VSP groups for each three engine stress modes (low, medium and high) and 60 bins for each monitored vehicle type per hour. These data are a required input for the IVE model [4]. The GPS data were also used to identify the start pattern that consists of number of start and the engine soak time that is an important determinant of the vehicle exhaust emission. A high emission is generated during a cold start, i.e., a start when the engine has completely been cooled off.

\section{Vehicle flow monitoring}

Vehicle counting was done manually at nine selected roads, one location for each road in HCMC, Da Nang and Vinh, for three periods in a monitoring day (07:00-09:00 and 17:00-19:00 to cover rush hours, and 10:00-11:00 and 13:0015:00 to cover normal hours. Therefore, for every selected road, a total of 180 minutes of vehicle counting was recorded (continuously counting over 15 minutes followed by a 10minute break).

\section{Secondary data collection}

Hourly temperature and humidity in Hanoi were given from the Weather Underground website www.wunderground.com. The data on fuel characteristics were extracted from the information by the standards of Petrolimex and the Vietnam National Petroleum Corporation (VNPC). All the data were used in the location input file of IVE.

\subsection{IVE modeling}

Large number of default vehicle technologies, which are identified by engine technology, vehicle weight, mileage, fuel used, air/fuel control and exhaust control devices are incorporated in IVE model.

All the collected primary data were processed to prepare the two input files (Fleet Input file and Location Input file). The third input file (Base adjustment file) is an optional file because this only generates when the local $\mathrm{EF}$ data are available. For the output of fifteen default pollutants in IVE, nine pollutants were analyzed in this study which included pollutants affecting air quality $\left(\mathrm{CO}, \mathrm{VOC}, \mathrm{VOC}_{\text {evap }}, \mathrm{NO}_{\mathrm{x}}\right.$, $\left.\mathrm{SO}_{\mathrm{x}}, \mathrm{PM}_{10}\right)$ and GHGs $\left(\mathrm{CO}_{2}, \mathrm{~N}_{2} \mathrm{O}, \mathrm{CH}_{4}\right)$.

With the hypothesis that early actions to improve the vehicle technologies can contribute to improve air quality, mitigation of climate change and protect the public health, faster intrusion scenario of fuel change and compliance with Euro IV were also examined according to the vehicle technology road map of Vietnam.

\subsection{Emission reduction scenarios}

The emission inventory (EI) for buses in HCMC, taxis in Da Nang and Vinh were produced for the base case of 2013. In addition, three scenarios with faster technology-intrusion scenario were conducted which assumed that $100 \%$ buses in HCMC, $100 \%$ taxis in Da Nang and Vinh using CNG (Scenario 1), LPG (Scenario 2) and comply with Euro IV (Scenario $3)$, respectively.

\subsection{Co-benefit}

\section{Co-benefits of climate and air quality}

Co-benefits of climate and air quality were calculated following the methodology, which is presented in detail in our previous studies [6-8].

\section{Co-benefit of health}

To evaluate health benefits related with the control scenarios of air pollution for public transport in three cities we assumed that the 
Changes in

$\mathrm{EF}$

people are exposed only to pollutants, which are emitted from public transport activities. In addition, in each city, all other factors are equal in all scenarios except the EF in each scenario. Co-benefit of health associated with the proposed scenarios are, therefore, estimated based on the changes in ambient air pollutant concentrations, that are converted into the changes in health effects, as illustrated above.

To calculate the concentrations of air pollutants at a location which relate to the emission of roadway we used the improved air pollutant dispersion model from roadway traffic of Régis et.al (2011) [9].

AirQ+ model was used to estimate the health effects. This model is proposed by World Health Organization for the assessment of the health

\section{Change in ambient pollutant concentrations}

\section{Change in} health effects

effects by air pollutants such as $\mathrm{PM}_{2.5}, \mathrm{PM}_{10}$, $\mathrm{NO}_{2}, \mathrm{O}_{3}$, black carbon (BC). AirQ+ also enables users to load their own data for pollutants not included in AirQ+ if relative risks (RRs) are available [10]. In which, the RRs are used based on the epidemiology study results of Vietnam and some other countries in Asia (Table 2).

\section{Results and discussion}

\subsection{Emission factors of public transport in the cities}

Average emission factors (EF) of public transport in weekdays (WDs) and weekends (WKs) for the base state are shown in Table 3.

\begin{tabular}{|c|c|c|c|c|}
\hline \multicolumn{5}{|c|}{ Data collection } \\
\hline Data of bus specifications & Traffic flow & \multicolumn{2}{|c|}{ Data of on-road driving pattern } & Secondary data \\
\hline \multicolumn{5}{|c|}{ L } \\
\hline \multicolumn{5}{|c|}{ Data analysis } \\
\hline Survey analysis & $\begin{array}{l}\text { Determination of } \\
\text { traffic flow }\end{array}$ & S data analysis & \multicolumn{2}{|c|}{$\begin{array}{l}\text { Meteorological parameters, fuel } \\
\text { characteristics }\end{array}$} \\
\hline \multicolumn{5}{|c|}{ L } \\
\hline \multicolumn{5}{|c|}{ Setting up scenarios } \\
\hline \multicolumn{2}{|c|}{ The base state } & \multicolumn{3}{|c|}{ Scenarios } \\
\hline \multicolumn{5}{|c|}{5} \\
\hline \multicolumn{5}{|c|}{ Running vehicle emission model (IVE model) } \\
\hline \multicolumn{2}{|c|}{ EF of the state base } & \multicolumn{3}{|c|}{ EF of scenarios } \\
\hline \multicolumn{5}{|c|}{5} \\
\hline \multicolumn{5}{|c|}{ Results and discussion } \\
\hline
\end{tabular}

Figure 1. Framework of methodology. 
Table 1. Summary of selected roads for three study area

\begin{tabular}{lllll}
\hline City & Zone & Highways & Arterial roads & Residental roads \\
\multirow{4}{*}{ Ho Chi Minh } & A & Nguyen Van Linh & Nguyen Thi Thap & Le Van Luong \\
& B & Dong Tay Boulevard & Le Duan & Nguyen Thi Minh Khai \\
& C & Hanoi highway & Kha Vạn Can & Vo Van Ngan \\
Da Nang & A & Dien Bien Phu & Nguyen Tri Phuong & Ham Nghi \\
& B & 2-9 & Le Duan & Trieu Nu Vuong \\
& C & Ngu Hanh Son & Ho Xuan Huong & Ba Huyen Thanh Quan \\
Vinh & A & Lenin & Nguyen Sy Sach & Kim Dong \\
& B & Le Duan & Nguyen Van Troi & Cu Chinh Lan \\
& C & Quang Trung & Nguyen Thi Minh Khai & Dang Tat \\
\hline
\end{tabular}

Table 2. Relative risks for selected pollutants

\begin{tabular}{|c|c|c|c|c|}
\hline \multirow[t]{2}{*}{ Health outcomes } & \multicolumn{3}{|c|}{$\begin{array}{l}\text { Relative risks (with increase of } \\
\text { concentration is } 10 \mu \mathrm{g} / \mathrm{m}^{3} \text { ) }\end{array}$} & \multirow[t]{2}{*}{ Sources } \\
\hline & $\mathrm{NO}_{\mathrm{x}}$ & $\mathrm{SO}_{2}$ & $\mathrm{PM}_{2.5}$ & \\
\hline $\begin{array}{l}\text { Hospital admissions for acute lower respiratory } \\
\text { infections (ALRI) in young children }\end{array}$ & - & 1.077 & - & [11] \\
\hline Mortality from all non-accidental causes & 1.014 & 1.019 & 1.009 & \\
\hline Cardiovascular mortality & - & - & 1.016 & {$[12,13]$} \\
\hline Respiratory mortality & - & - & 1.022 & \\
\hline Acute conjunctivitis & 1.06 & - & & \\
\hline Chronic conjunctivitis & 1.10 & - & - & [14] \\
\hline
\end{tabular}

Table 3. $\mathrm{EF}_{\text {running }}$ of vehicles in the studied cities $(\mathrm{g} / \mathrm{km})$

\begin{tabular}{|c|c|c|c|c|c|c|c|c|c|c|c|}
\hline \multirow{3}{*}{$\begin{array}{l}\text { Pollutants } \\
\mathrm{CO}\end{array}$} & \multicolumn{4}{|c|}{ Taxi in Vinh } & \multicolumn{4}{|c|}{ Taxi in Da Nang } & \multicolumn{3}{|c|}{ Bus in Ho Chi Minh } \\
\hline & \multicolumn{2}{|c|}{ Average } & \multirow{2}{*}{$\begin{array}{l}\text { WKs } \\
9.86\end{array}$} & \multirow{2}{*}{$\begin{array}{l}\text { WDs } \\
10.4\end{array}$} & \multicolumn{2}{|c|}{ Average } & \multirow{2}{*}{$\begin{array}{c}\text { WKs } \\
12.69\end{array}$} & \multirow{2}{*}{$\begin{array}{c}\text { WDs } \\
16.6\end{array}$} & Average & \multirow{2}{*}{$\begin{array}{l}\text { WKs } \\
3.06\end{array}$} & \multirow{2}{*}{$\frac{\text { WDs }}{3.19}$} \\
\hline & $\begin{array}{l}10.13 \pm \\
0.53\end{array}$ & $\begin{array}{l}(11.38 \pm \\
0.32)\end{array}$ & & & $\begin{array}{l}14.64 \pm \\
3.83\end{array}$ & $\begin{array}{l}(15.25 \pm \\
0.45)\end{array}$ & & & $\begin{array}{ll}3.13 \pm & (3.47 \pm \\
0.09 & 0.58)\end{array}$ & & \\
\hline VOC & $\begin{array}{l}0.70 \pm \\
0.28\end{array}$ & $\begin{array}{l}(1.10 \pm \\
0.05)\end{array}$ & 0.56 & 0.85 & $\begin{array}{l}1.04 \pm \\
0.23\end{array}$ & $\begin{array}{l}(1.70 \pm \\
0.08)\end{array}$ & 0.93 & 1.16 & $\begin{array}{ll}0.68 \pm & (0.83 \pm \\
0.02 & 0.15) \\
\end{array}$ & 0.67 & 0.7 \\
\hline $\begin{array}{l}\mathrm{NOx} \\
\text { (as N) }\end{array}$ & $\begin{array}{l}0.54 \pm \\
0.22\end{array}$ & $\begin{array}{l}(0.74 \pm \\
0.02)\end{array}$ & 0.38 & 0.7 & $\begin{array}{l}0.76 \pm \\
0.21\end{array}$ & $\begin{array}{l}(0.96 \pm \\
0.13)\end{array}$ & 0.68 & 0.84 & $\begin{array}{ll}23.16 & (26.91 \pm \\
\pm 0.44 & 4.53)\end{array}$ & 22.85 & 23.48 \\
\hline $\mathrm{SO}_{2}$ & $\begin{array}{l}0.07 \pm \\
0.01\end{array}$ & $\begin{array}{l}(0.085 \pm \\
0.007)\end{array}$ & 0.06 & 0.08 & $\begin{array}{l}0.07 \pm \\
0.01\end{array}$ & $\begin{array}{l}(0.115 \pm \\
0.007)\end{array}$ & 0.07 & 0.08 & $\begin{array}{ll}0.11 \pm & (0.12 \pm \\
0.00 & 0.019) \\
\end{array}$ & 0.11 & 0.11 \\
\hline PM & $\begin{array}{l}0.01 \pm \\
0.00\end{array}$ & $\begin{array}{l}(0.013 \pm \\
0.001)\end{array}$ & 0.01 & 0.01 & $\begin{array}{l}0.01 \pm \\
0.01\end{array}$ & $\begin{array}{l}(0.02 \pm \\
0.00)\end{array}$ & 0.01 & 0.02 & $\begin{array}{ll}6.26 \pm & (7.69 \pm \\
0.16 & 1.28)\end{array}$ & 6.14 & 6.37 \\
\hline $\mathrm{CO}_{2}$ & $\begin{array}{l}340.54 \pm \\
77.11\end{array}$ & $\begin{array}{l}(392.56 \pm \\
26.88)\end{array}$ & 284.9 & 396.17 & $\begin{array}{l}351.97 \pm \\
53.04\end{array}$ & $\begin{array}{l}(545.78 \\
\pm 33.21) \\
\end{array}$ & 312.81 & 391.13 & $\begin{array}{ll}1079 & (1202 \pm \\
\pm 24 & 191) \\
\end{array}$ & 1062 & 1097 \\
\hline $\mathrm{N}_{2} \mathrm{O}$ & $\begin{array}{l}0.03 \pm \\
0.01 \\
\end{array}$ & $\begin{array}{l}(0.030 \pm \\
0.002) \\
\end{array}$ & 0.02 & 0.03 & $\begin{array}{l}0.04 \pm \\
0.01 \\
\end{array}$ & $\begin{array}{l}(0.04 \pm \\
0.00)\end{array}$ & 0.03 & 0.04 & $\begin{array}{ll}0.01 \pm & (0.01 \pm \\
0.00 & 0.0015) \\
\end{array}$ & 0.01 & 0.01 \\
\hline $\mathrm{CH}_{4}$ & $\begin{array}{l}0.13 \pm \\
0.04\end{array}$ & $\begin{array}{l}(0.205 \pm \\
0.008)\end{array}$ & 0.1 & 0.16 & $\begin{array}{l}0.20 \pm \\
0.06\end{array}$ & $\begin{array}{l}(0.32 \pm \\
0.01)\end{array}$ & 0.18 & 0.22 & $\begin{array}{l}0.02 \pm \quad 0 \\
0.00\end{array}$ & 0.02 & 0.02 \\
\hline Note & $\begin{array}{l}\text { The } \\
\text { of } t\end{array}$ & $\begin{array}{l}\text { values in ( ) } \\
\text { xi in Quang }\end{array}$ & $\begin{array}{l}\text { are the } \\
\text { Ninh }\end{array}$ & & $\begin{array}{l}\text { The } \\
\text { of }\end{array}$ & $\begin{array}{l}\text { alues in }( \\
\text { taxi in } \mathrm{H}_{2}\end{array}$ & $\begin{array}{l}\text { are the } \\
\text { Noi [7] }\end{array}$ & & $\begin{array}{c}\text { The values in } \\
\text { of bus in }\end{array}$ & $\begin{array}{l}\text { are th } \\
\text { Noi }[6\end{array}$ & \\
\hline
\end{tabular}


It can be seen from Table 3 that all EFs in weekdays are higher than those in weekends reflecting real traffic conditions in big cities. In addition, the $\mathrm{CO}$ emission factor of vehicles using gasoline fuel is always higher than that using diesel fuel, even its load is higher. This result is similar with the other studies in Vietnam [6-8], and the study in [15]. For the same vehicle type (such as taxi), the emission factor of all pollutants in Da Nang city are higher than those in Vinh city. This can be explained by the fact that Da Nang is centrally-run grade I city so the vehicle density is higher, the taxi flow in Da Nang was 81 vehicles per hour while only 46 vehicles per hour were counted in Vinh.

\subsection{Co-benefits of climate change mitigation}

\section{Benefits of air quality}

Benefits of air quality for public transports in big cities are identified depend on changes of the $\mathrm{EF}$ in scenarios comparing with them in base state. Benefits of air quality are shown in Table 4.

It can be seen from Table 4 that almost all EF in three proposed scenarios are decreased comparing with the base state with some exceptions.

CNG and LPG generally contain practically zero $\mathrm{S}$ (except trace amount in the odorant (mercaptan) added to gas for safety reasons), whereas DO contain a certain amount. That is why switching from DO to CNG or LPG can reduce the almost emission of $\mathrm{SO}_{2}$, the $\mathrm{SO}_{2}$ emission reducing efficiency can reach up to $98 \%$ in all scenarios related to switching fuel. In addition, these fuels have simpler molecules than DO then their combustion is more likely to be completed than DO, leading to lower VOC and PM emission. The results in Table 2 also shown that using CNG fuel can reduce NOx emission, around $3 \%$ and $98 \%$ for converting from gasoline and diesel fuel to CNG. These results are conformity to the other study results, which were presented in $[6-8,15]$. The reduction of NOx and VOC emissions lead to the decrease of the formation of ground ozone as well as secondary $\mathrm{PM}$ such as $\mathrm{PM}_{10}$ and $\mathrm{PM}_{2.5}$ in the ambient air. This point is very important in terms of air quality improving.
The increase of $\mathrm{CO}$ and $\mathrm{CH}_{4}$ in scenarios related to switching fuel (except cases converting from gasoline to LPG) can also be explainable. $\mathrm{CH}_{4}$ is the major component of CNG and the second component of LPG but it is absent in diesel oil. In addition, it is reported that, for low carbon fuel such as CNG and LPG, higher emission of $\mathrm{CO}$ is found due to less mixing of air and gaseous fuel [15]. The results in Table 2 are conformity to the study of Abdullah Yasar et.al. [15].

On the other hand, when the public transports meet the EURO IV standards, their exhaust is strictly controlled/treated leading to lower emissions of all air pollutants.

\section{Benefits of climate}

The reduction of GHG emissions as $\mathrm{CO}_{2} \mathrm{eq}$ for the proposed scenarios is presented in Table 5.

The reduction of carbon dioxide equivalent $\left(\mathrm{CO}_{2}\right.$ eq $)$ associated with the three selected scenarios is shown in Table 5. All the scenarios lead to $\mathrm{CO}_{2}$ eq reductions from around $15 \%$ to $89 \%$, in which complying with Euro IV is the best option. The obtained climate benefits of bus system are higher than the taxi system. This can be explained by the fact that the diesel combustion releases more pollutants than gasoline combustion, in which $\mathrm{BC}$ is a substance has 20-year GWP equal 4.470 [16].

Using the online greenhouse gas equivalencies calculator tool of US Environmental Protection Agency (EPA) we can see that 1 ton $\mathrm{CO}_{2}$ eq reduced is equivalent to greenhouse gas emissions from 0.211 passenger vehicles driven for one year, or 2.397 miles driven by an average passenger vehicle, or 0.371 tons of waste recycled instead of being landfilled; or equivalent to $\mathrm{CO}_{2}$ emissions from 113 gallons of gasoline consumed, or 1067 Pounds of coal burned [17].

\section{Benefits of health}

In this study, we used $\mathrm{EF}_{\text {running, which is }}$ determined when the vehicle is running, so PM predominantly found in the fine fraction $\left(\mathrm{PM}_{2.5}\right)$ $[18,19] . \mathrm{PM}_{2.5}$, therefore, is used to estimate 
benefits of health. The benefits of health are assessed based on the reduction of health effects related to the reduction of pollutant emissions in the proposed scenarios. In this study, the health effects are calculated only for the long-term exposure of $\mathrm{PM}_{2.5}, \quad \mathrm{SO}_{2}$ and $\mathrm{NO}_{\mathrm{x}}$. These pollutants are normally used in studies about the effects of transport-related air pollutants on mortality and hospital admissions [20, 21]. The obtained health benefits are shown in Table 6 .

The results of health impact assessment due to long-term exposure in Table 6 shows that the health benefits associated with reduction of $\mathrm{PM}_{2.5}, \mathrm{SO}_{2}$ and $\mathrm{NO}_{\mathrm{x}}$ can be achieved when applying different emission control scenarios for public transport in the three cities. In which, the health-benefit from the bus system is more significant than the taxi system. In addition, the health-benefit for the bus system is obtained from fuel switching scenario is higher than emission control standard tightening scenario. By contrast, for the taxi system, fuel switching scenario provides less health-benefit than Euro IV implementation scenario. This can be explained by the fact that switching from DO to CNG or LPG could bring higher emission reduction in comparison with switching from gasoline to CNG or LPG (Table 6). Besides, the health benefits of the taxi system in Da Nang that are achieved from these scenarios are quite similar to the taxi system in Vinh.

Table 4. Benefits of air quality for public transport in big cities (\%)

\begin{tabular}{|c|c|c|c|c|c|c|c|c|c|}
\hline \multirow{3}{*}{ Pollutants } & \multicolumn{6}{|c|}{ Switching fuel } & \multicolumn{3}{|c|}{$\begin{array}{l}\text { Meeting the emission } \\
\text { standards EURO IV }\end{array}$} \\
\hline & \multicolumn{2}{|c|}{$\begin{array}{c}\text { Bus in Ho Chi } \\
\text { Minh }\end{array}$} & \multicolumn{2}{|c|}{ Taxi in Da Nang } & \multicolumn{2}{|c|}{ Taxi in Vinh } & \multirow{2}{*}{$\begin{array}{l}\text { Bus in Ho } \\
\text { Chi Minh }\end{array}$} & \multirow{2}{*}{$\begin{array}{l}\text { Taxi in } \\
\text { Da Nang }\end{array}$} & \multirow{2}{*}{$\begin{array}{l}\text { Taxi in } \\
\text { Vinh }\end{array}$} \\
\hline & $\mathrm{CNG}$ & LPG & $\mathrm{CNG}$ & LPG & $\mathrm{CNG}$ & LPG & & & \\
\hline $\mathrm{CO}$ & $\uparrow$ & $\uparrow$ & -30.46 & -30.46 & -20.25 & -20.25 & -88.71 & -79.44 & -86.36 \\
\hline VOC & -93.42 & -44.59 & -94.87 & -57.99 & -96.44 & -70.37 & -95.03 & -88.91 & -89.08 \\
\hline $\begin{array}{l}\mathrm{NO}_{\mathrm{x}} \\
(\text { as N)}\end{array}$ & -98.70 & -98.45 & -3.58 & $\uparrow$ & -3.78 & $\uparrow$ & -77.42 & -63.02 & -64.77 \\
\hline $\mathrm{SO}_{\mathrm{x}}$ & -98.13 & -98.13 & -98.80 & -98.80 & -98.78 & -98.78 & -17.76 & -24.83 & -25.58 \\
\hline PM & -99.92 & -99.84 & -95.92 & -91.85 & -95.92 & -91.84 & -93.19 & -62.75 & -62.71 \\
\hline $\mathrm{CO}_{2}$ & -38.06 & -33.42 & -25.37 & -16.35 & -22.22 & -18.36 & -19.39 & -19.30 & -14.11 \\
\hline $\mathrm{CH}_{4}$ & $\uparrow$ & $\uparrow$ & $\uparrow$ & -35.00 & $\uparrow$ & -38.46 & -88.71 & -90.00 & -92.31 \\
\hline
\end{tabular}

Table 5. Emission of $\mathrm{CO}_{2} \mathrm{eq}$ and respective reduction associated with the selected scenarios (for 20 years)

\begin{tabular}{llllll}
\hline \multirow{2}{*}{ Results in this study } & \multirow{2}{*}{ Item } & \multirow{2}{*}{ Base state } & \multicolumn{3}{l}{ Scenarios } \\
\cline { 4 - 6 } & & & CNG & LPG & Euro IV \\
\hline \multirow{2}{*}{ Bus in Ho Chi Minh } & Emission of $\mathrm{CO}_{2}$ eq, ton/year & 1231.09 & 145.33 & 132.35 & 173.47 \\
& Reduction of $\mathrm{CO}_{2}$ eq, \% & & 88.2 & 89.25 & 85.91 \\
Taxi in Da Nang & Emission of $\mathrm{CO}_{2}$ eq, ton/year & 27.41 & 22.53 & 22.33 & 17.50 \\
& Reduction of $\mathrm{CO}_{2}$ eq, \% & & 17.80 & 18.53 & 36.16 \\
Taxi in Vinh & Emission of $\mathrm{CO}_{2}$ eq, ton/year & 16.41 & 13.94 & 13.54 & 11.57 \\
Comparison with other studies & Reduction of $\mathrm{CO}_{2}$ eq, \% & & 15.03 & 17.52 & 29.51 \\
Bus in Ha Noi [6] & & & & & \\
Taxi in Ha Noi [7] & Reduction of $\mathrm{CO}_{2}$ eq (\%) & & 32.1 & 85.8 & \\
Taxi in Quang Ninh [8] & & & 13.0 & 13.4 & 54.9 \\
\hline
\end{tabular}


Table 6. Evaluate health benefits of reducing $\mathrm{PM}_{2.5}, \mathrm{SO}_{2}$ and $\mathrm{NOx}$ emission for the selected scenarios

\begin{tabular}{|c|c|c|c|c|c|c|c|c|}
\hline \multirow{3}{*}{$\begin{array}{l}\text { Results in } \\
\text { this study }\end{array}$} & \multirow{3}{*}{$\begin{array}{c}\text { Health effects } \\
\text { (Health indicators) }\end{array}$} & \multicolumn{7}{|c|}{ Health data (all ages) } \\
\hline & & \multicolumn{4}{|c|}{ Number of cases per year } & \multicolumn{3}{|c|}{ Reduction $(\%)$} \\
\hline & & $\begin{array}{l}\text { Base } \\
\text { state }\end{array}$ & $\mathrm{CNG}$ & LPG & $\begin{array}{l}\text { Euro } \\
\text { IV }\end{array}$ & $\mathrm{CNG}$ & LPG & $\begin{array}{c}\text { Euro } \\
\text { IV }\end{array}$ \\
\hline \multirow{6}{*}{$\begin{array}{l}\text { Bus in } \\
\text { HCMC }\end{array}$} & $\begin{array}{l}\text { Hospital admissions for acute } \\
\text { lower respiratory infections } \\
\text { (ALRI) in young children }\end{array}$ & 170 & 168 & 168 & 169 & 1.2 & 1.2 & 0.6 \\
\hline & $\begin{array}{l}\text { Mortality from all non- } \\
\text { accidental causes }\end{array}$ & 189 & 153 & 153 & 154 & 19.0 & 19.0 & 18.5 \\
\hline & Cardiovascular mortality & 143 & 134 & 134 & 135 & 6.3 & 6.3 & 5.6 \\
\hline & Respiratory mortality & 190 & 179 & 179 & 180 & 5.8 & 5.8 & 5.3 \\
\hline & Acute conjunctivitis & 225 & 114 & 114 & 139 & 49.3 & 49.3 & 38.2 \\
\hline & Chronic conjunctivitis & 338 & 179 & 180 & 217 & 47.0 & 46.7 & 35.8 \\
\hline \multirow{6}{*}{$\begin{array}{l}\text { Taxi in } \\
\text { Da Nang } \\
\text { city }\end{array}$} & $\begin{array}{l}\text { Hospital admissions for acute } \\
\text { lower respiratory infections } \\
\text { (ALRI) in young children }\end{array}$ & 169 & 168 & 168 & 169 & 0.6 & 0.6 & 0.0 \\
\hline & $\begin{array}{l}\text { Mortality from all non- } \\
\text { accidental causes }\end{array}$ & 154 & 154 & 154 & 153 & 0.0 & 0.0 & 0.6 \\
\hline & Cardiovascular mortality & 134 & 134 & 134 & 134 & 0.0 & 0.0 & 0.0 \\
\hline & Respiratory mortality & 179 & 179 & 179 & 179 & 0.0 & 0.0 & 0.0 \\
\hline & Acute conjunctivitis & 116 & 116 & 116 & 114 & 0.0 & 0.0 & 1.7 \\
\hline & Chronic conjunctivitis & 183 & 182 & 183 & 179 & 0.5 & 0.0 & 2.2 \\
\hline \multirow{6}{*}{$\begin{array}{l}\text { Taxi in } \\
\text { Vinh city }\end{array}$} & $\begin{array}{l}\text { Hospital admissions for acute } \\
\text { lower respiratory infections } \\
\text { (ALRI) in young children }\end{array}$ & 169 & 168 & 168 & 169 & 0.6 & 0.6 & 0.0 \\
\hline & $\begin{array}{l}\text { Mortality from all non- } \\
\text { accidental causes }\end{array}$ & 154 & 153 & 154 & 153 & 0.6 & 0.0 & 0.6 \\
\hline & Cardiovascular mortality & 134 & 134 & 134 & 134 & 0.0 & 0.0 & 0.0 \\
\hline & Respiratory mortality & 179 & 179 & 179 & 179 & 0.0 & 0.0 & 0.0 \\
\hline & Acute conjunctivitis & 115 & 115 & 115 & 113 & 0.0 & 0.0 & 1.7 \\
\hline & Chronic conjunctivitis & 181 & 181 & 181 & 178 & 0.0 & 0.0 & 1.7 \\
\hline
\end{tabular}
Note: Estimating health effects is based population size of 100000 persons.

\section{Conclusion}

The study determines quantitatively the cobenefits of health, climate and air quality for the public transport system associated with the three control scenarios. It is found that the fuel switching from diesel to either CNG or LPG as well as the tightening of the emission standards to EURO IV significantly contribute to the mitigation of climate change, the improvement of air quality and the reduction of health effects. Of which, the fuel switching from diesel to CNG would obtain the highest benefits to either environment or health.

\section{References}

[1] Tran Thu Trang, Huynh Hai Van, Nguyen Thi Kim Oanh, Traffic emission inventory for estimation of air quality and climate co-benefits of faster technology intrusion in Hanoi, Journal of Carbon Management 6 (2015) 117-128. https://doi.org/10.1080/17583004.2015.109369.

[2] MONRE, National State of Environment Vietnam Urban Air Environment 2007. http://vea.gov.vn/vn/hientrangmoitruong/baocao mtquocgia (accessed 17 April 2018).

[3] World Health Organization (WHO), Burden of disease from Ambient Air Pollution for 2012 Summary of results. https://www.who.int/phe/ health_topics/outdoorair/databases (accessed 20 
May 2018).

[4] International Sustainable Systems Research Center ISSRC, IVE Model User's Manual Version 2.0. http://www.issrc.org/ive (accessed 21 June 2015).

[5] J. L. Jimenez, Understanding and Quantifying Motor Vehicle Emissions with Vehicle Specific Power and TILDES Remote Sensing, Massachusetts Institute of Technology, Massachusetts, 1999.

[6] Nguyen Thu Trang, Nghiem Trung Dung, Tran Thu Trang, Potentiality of Co-benefits of climate and air quality in fuel switching for Hanoi bus system, Journal of Science and Technology 49 (2011) 117-128. https://doi.org/10.15625/0866708X/49/4/1883.

[7] Nghiem Trung Dung, Tran Thi Nhung, Tran Thu Trang, Co-benefits of air quality and climate for taxi system in Hanoi associated with selected control scenarios, Journal of Science and Technology 51 (2013) 104-111.

[8] Nghiem Trung Dung, Ho Tuan Anh (2014). Climate and air quality co-benefits of improving taxi system in Ha Long city, Quang Ninh, Journal of Science and Technology 52 (2014) 185 - 194. https://doi.org/10.15625/0866-708X/52/2/3366.

[9] Régis Briant, Irène Korsakissok, Christian Seigneur, An improved line source model for air pollutant dispersion from roadway traffic, Atmospheric Environment 44 (2011) 4099-4107. https://doi.org/10.1016/j.atmosenv.2010.11.016.

[10] World Health Organization (WHO), AirQ+: software tool for health risk assessment of air pollution. http://www.euro.who.int/en/health-topics/ environment-and-health/air-quality/ activities/airqsoftware-tool-for-health-risk-assessment-of-airpollution (accessed 10 August 2018).

[11] Long Ngo, Sumi Mehta, Dung Do, Thuan Thach, The Effects of Short-term Exposure on Hospital Admissions for Acute Lower Respiratory Infections in Young Children of Ho Chi Minh City, Viet Nam, Epidemiology 22 (2011) S228S229. https://doi.org/10.1097/01.ede.0000392389. 28666.ed.

[12] Hyunjoo Bae, Jeongim Park, The Effects of Fine and Coarse Particles on Daily Mortality in Seoul, Korea, Epidemiology 22 (2011) S228. https:// doi.org/10.1097/01.ede.0000392386.38968.bd.
[13] Haidong Kan, Dongfeng Gu, Association between Long-term Exposure to Outdoor Air Pollution and Mortality in China: A Cohort Study, Epidemiology 22 (2011) S29. https://doi.org/10.1016/j.jhazmat.2010.12.036.

[14] Yu-Chun Wang, Chun-Chi Chiang, Fung-Chang Sung, Chien-Chang Liao, Pei-Chun Chen, Increased Risk of Acute and Chronic Conjunctivitis Associated with Ambient Air Quality in Taiwan, Epidemiology 22 (2011) S222. https://doi.org/10.1097/01.ede.0000392366. 62731.27 .

[15] Abdullah Yasar, Rizwan Haider, Amtul Bari Tabinda, Fidous Kausar, Maryam Khan, A Comparison of Engine Emissions from Heavy, Medium, and Light Vehicles for CNG, Diesel, and Gasoline Fuels, Polish Journal of Environmental Studies 22 (2013) 1277-1281.

[16] U.S. Environmental Protection Agency, Report to Congress on Black Carbon, Chapter 2: Black Carbon and Its Effects on Climate. https://cfpub.epa.gov/si/si_public_record_report. $\mathrm{cfm}$ ?Lab=OAQPS\&dirEntryID=240148 (accessed 10 August 2018).

[17] U.S. Environmental Protection Agency, GHG Equivalencies Calculator - Calculations and References. https://www.epa.gov/energy/ghgequivalencies-calculator-calculations-andreferences (accessed 15 August 2018).

[18] Matthias Ketzel, Gunnar Omstedt, Christer Johansson, Ingo During, Mia Pohjola, Dietmar Oettl, Ruwim Berkowicz, Estimation and validation of $\mathrm{PM} 2.5 / \mathrm{PM}_{10}$ exhaust and nonexhaust emission factors for practical street pollution modelling, Atmospheric Environment 41 (2007) 9370 - 9385.

[19] C.A. Brebbia, J.W.S. Longhurst, Air Pollution XVI: Definition of $\mathrm{PM}_{10}$ emission factors from traffic: use of tracers and definition of background concentration, WIT Pres, 2008.

[20] Mazouzi Raja, Health benefits of cleaner fuels: Unleaded gasoline and low sulfur Fuel, Ministry of Public Health, Directorate of hygiene and Environmental Protection, 2009.

[21] The Government of the Hong Kong Special Administrative Region of the People's Republic of China, Expansion of Hong Kong International Airport into a Three-Run. 